\begin{tabular}{c} 
JURNAL EINSTEIN \\
Jurnal Hasil Penelitian Bidang Fisika \\
$\begin{array}{c}\text { Available online http://jurnal.unimed.ac.id/2012/index.php/inpafi } \\
\text { e-issn: } 2407-747 x, p-i s s n ~ 2338-1981\end{array}$ \\
\hline
\end{tabular}

\title{
Identifikasi Sebaran Situs Purbakala Di Desa Lobu Tua Kabupaten Tapanuli Tengah Dengan Menggunakan Metode Geolistrik Dan Penginderaan Jauh
}

\author{
Indriani Sutama dan Muhammad Kadri \\ Jurusan Fisika, Fakultas Matematika dan Ilmu Pengetahuan Alam, \\ Universitas Negeri Medan, Indonesia \\ Indrisutama60@gmail.com
}

Diterima: Desember 2016; Disetujui: Januari 2017; Dipublikasikan: Februari 2017

\begin{abstract}
ABSTRAK
Telah dilakukan penelitian dengan memanfaatkan Resistivitas bawah permukaan dan memanfaatkan citra satelit Landsat 8 OLI dengan tujuan untuk menentukan penyebaran resistivitas bawah permukaan bumi secara vertikal dan horizontal serta memetakan permukaan daerah bersejarah di Desa Lobu Tua menggunakan metode Geolistrik konfigurasi Schlumberger dan Penginderaan Jauh. Data pengukuran dilapangan diolah untuk mendapatkan gambar penampang kontur nilai resistivitas perlapisan dan penyebaran batuan dengan menggunakan software Res2Dinv dan untuk penginderaan jauh yang memanfaatkan data citra satelit landsat 8 OLI Path 129 Row 58. Data diolah menggunakan software Envi 4.7 dan ArcGIS 10.0 untuk memperoleh peta permukaan daerah Lobu Tua. Hasil penelitian menunjukkan adanya anomali batuan andesit sebagai batuan penyusun situs purbakala dengan nilai resistivitas $1313 \Omega \mathrm{m}-$ $1820 \Omega \mathrm{m}$. keberadaan batuan andesit bervariasi pada kedalaman 5 meter sampai 25 meter dan jarak 20 meter sampai 140 meter. struktur lapisan pada setiap lintasan terdapat lapisan alluvium yang terdiri dari pasir dan kerikil dengan nilai resistivitas $44,8 \Omega \mathrm{m}-1059 \Omega \mathrm{m}$. berdasarkan data penginderaan jauh diketahui daerah Lobu Tua didominasi oleh endapan batuan alluvium dengan kemiringan lereng $0-0.6 \%$.
\end{abstract}

Kata Kunci: Geolistrik, Res2Dinv, Citra Satelit, Envi 4.7, ArcGIS 10.0, andesit, alluvium

PENDAHULUAN

Indonesia adalah Negara yang sangat luas yang memiliki banyak warisan budaya dan peninggalan budaya dimasa lampau (Hendro, 2005). Salah satu peninggalan dimasa lampau adalah peninggalan situs purbakala Kerajaan Barus di Desa Lobu Tua Kecamatan Andam Dewi Kabupaten Tapanuli Tengah.
Situs Lobu Tua merupakan situs kuno yang berada di Barus, Situs kuno Lobu Tua merupakan situs tertua di daerah tersebut yang diperkirakan situs ini dihuni antara abad VIII/IX M dan abad XII/XIII M.

Di Situs Lobu Tua pada tahun 1978 dan 1985 telah dilakukan penggalian yang dipimpin oleh Nurhadi dan Lukman Nurhakim dari Pusat Penelitian Arkeologi Nasional. menghasilkan 
lebih dari 300 pecahan keramik Cina (sebagian besar dari Dinasti Song), pecahan-pecahan tembikar, kaca, logam, dan manik-manik (Guillot, 2014).

Tahun 1858 M Friederich juga meneliti beberapa prasasti pendek yang diukir pada cincin dari emas yang ditemukan di Lobu Tua dengan kesimpulan bahwa cincin tersebut berumur sampai 800 atau 1.000 tahun. Ini berarti artefak (cincin) tersebut berasal dari pertengahan abad IX M hingga pertengahan abad XI M (Guillot, 2014).

Di situs kuno Lobu Tua tersimpan ribuan artefak dan pernah ditemukan sebuah prasasti berbahasa Tamil (menurut Hasan Muarif Ambary, 7/8 bagian prasasti ini disimpan di Museum Pusat dan 1/8 bagian masih di Lobu Tua) dan sebuah Torso tokoh Bodhisatwa. Kemudian di bagian dalam area situs yang berbenteng juga ditemukan sebuah prasasti berbahasa Jawa Kuno oleh seorang penduduk (Ambary, 2001).

Berdasarkan buku sejarah desa Lobu Tua dan melakukan tinjauan lokasi penelitian yaitu dengan mewawancarai beberapa masyarakat desa Lobu Tua bahwa di lokasi penelitian ada situs purbakala yang belum ditemukan, maka diperlukan eksplorasi benda bersejarah untuk mendeteksi ada tidaknya peninggalan situs purbakala yang masih terkubur.

Dalam pendugaan keadaan bawah permukaan bumi dengan melakukan pengukuran di atas permukaan diperlukan suatu pengukuran geofisika, salah satu metode pengukuran yang digunakan adalah pengukuran geolistrik. Dengan pengukuran geolistrik, variasi nilai resistivitas batuan bawah permukaan yang berasosiasi dengan keberadaan benda-benda megalitik di situs purbakala dapat diketahui. Metode geolistrik merupakan metode yang mempelajari sifat aliran listrik di dalam bumi dan cara untuk mendeteksi aliran di permukaan bumi. Hal ini meliputi pengukuran potensial dan pengukuran arus yang terjadi baik secara alamiah maupun akibat injeksi arus kedalam bumi. Oleh karena itu metode geolistrik mempunyai banyak macamnya, salah satunya adalah metode geolistrik tahanan jenis (resistivitas) (Hendrajaya, Idham, 1990).

Survei Geofisika untuk mendeteksi situs purbakala pernah dilakukan oleh E Galili, dkk (1988) di Creole ruralsettlements bagian tenggara Provinsi Buenos Aires, Argentina. Tujuan utama penelitian tersebut adalah untuk mendeteksi penyebaran benda-benda purbakala dan menentukan struktur perlapisan tanah dengan metode Geofisika. Hasil dari penelitian tersebut yaitu ditemukannya benda-benda seperti tulang-tulang, kaca dan batuan penyusun situs purbakala tersebut.

Hal serupa juga pernah dilakukan oleh Usmardin dan Sismanto pada tahun (2010) di Situs Purbakala Candi Palgading di Dusun Palgading, Desa Sinduharjo, Kecamatan Ngaglik, Kabupaten Sleman, Daerah Istimewa Yogyakarta dengan Menggunakan Metode Resistivitas Dipole Dipole. Tujuan dari penelitian tersebut yaitu untuk mengetahui penyebaran dan kedalaman batuan penyusun candi yang terpendam dalam tanah pada Situs Candi Palgading. Hasilnya menunjukkan nilai resistivitas batuan penyusun candi $750 \Omega \mathrm{m}$ sampai $5000 \Omega \mathrm{m}$ yang berada hingga kedalaman rata-rata $4,5 \mathrm{~m}$ sebagai batu andesit.

Selain dengan metode geolistrik, teknologi penginderaan jauh kini telah menjadi bagian dari alat yang biasa digunakan dalam industri pertambangan dan eksplorasi (Rokhmana, 2012).

Penginderaaan jauh merupakan suatu teknik untuk mengumpulkan informasi mengenai objek dan lingkungan dari jarak jauh tanpa sentuhan fisik melalui energi elektromagnetik. Biasanya teknik ini menghasilkan beberapa bentuk citra yang selanjutnya diproses dan diinterpretasi guna membuahkan data bermanfaat untuk aplikasi dibidang pertanian, arkeologi, kehutanan, geografi, geologi, perencanaan dan bidangbidang lainnya (Purbowaseso, Sutanto, 1995). 
Indriani Sutama dan Muhammad Kadri ; Identifikasi Sebaran Situs Purbakala di Desa Lobu Tua Kabupaten Tapanuli Tengah dengan Menggunakan Metode Geolistrik Dan Penginderaan Jauh

\section{METODE PENELITIAN}

Penelitian dilakukan di Desa Lobu Tua Kecamatan Andam Dewi Kabupaten Tapanuli Tengah, Sumatera Utara, Indonesia.

\section{Peralatan yang digunakan}

Dalam melakukan pengukuran identifikasi sebaran situs purbakala, metode yang digunakan yaitu satu set alat Geolistrik ARES-G4 v4.7, SN: 06091435 (Automatic Resistivity System) dan Penginderaan jauh memanfaatkan data citra landsat 8 OLI tahun 2016 yang dapat diakses dari usgs. GPS (global position system) yaitu alat untuk menentukan posisi berdasarkan hasil pantauan satelit.

Peralatan ini untuk mengukur nilai resistivits bawah permukaan tanah dan nilai spektrum elektromagnetik dari atas permukaan tanah.

\section{Geolistrik}

Teknik pengambilan data dalam penggunaan metode geolistrik yaitu:

Konfigurasi yang digunakan adalah Schlumberger dimana elektroda-elektroda potensial $\left(\mathrm{P}_{1}-\mathrm{P}_{2}\right)$ diam pada suatu tempat garis sentral $A B$, sedangkan elektroda-elektroda arus $\left(\mathrm{C}_{1}-\mathrm{C}_{2}\right)$ digerakkan secara simetri keluar dalam langkah-langkah tertentu dan sama. Pengukuran dalam penelitian ini dilakukan sebanyak 4 lintasan pengukuran dengan panjang lintasan 155 meter dan jarak spasi elektroda 5 meter.

Cara pengambilan datanya adalah sebagai berikut:

a. Mendownload data pada geolistrik ARES-G4v4.7, SN: 06091345.

b. Mengolah data yang diperoleh menggunakan software Res2Dinv.

c. Membedakan nilai tahanan jenis berdasarkan warna untuk melihat nilai resistivitas pada lintasan dari penampang 2D sepanjang lintasan.

d. Melakukan pengolahan data dengan software Surfer untuk penampang Secara Vertikal dan horizontal.

Berdasarkan gambar dan citra warna yang didapat dari hasil pengolahan Software
Res2Dinv maka dapat dilakukan interpretasi untuk memperlihatkan anomali bawah permukaan yang diukur.

\section{Penginderaan Jauh}

Teknik pengambilan data dalam metode penginderaan jauh:

Data pengolahan secara digital untuk menentukan penyebaran situs purbakala dapat didownload http://glovis.usgs.gov/. Data untuk pengolahan identifikasi situs purbakala dilakukan peninjauan langsung ke lapangan. Setelah data didapatkan dilakukan proses prapengolahan, pengolahan dan pasca pengolahan. Kemudian data hasil pasca pengolahan akan dilakukan teknik analisa data.

Proses pra-processing dilakukan dengan melakukan:

a. Koreksi radiometrik (untuk menghilangkan noise)

b. Melakukan pemotongan citra dengan menggunakan software ENVI 4.7 pada citra Landsat 8 OLI path/row : 129/58

Melakukan Proses Pengolahan

Membuat peta natural desa Lobu Tua dan kemiringan lereng tahun 2016

a. Menjalankan software ENVI 4.7

b. Untuk membuat peta natural, pada ENVI 4.7 menginput band 4 , band 3 dan band 2 dari citra Landsat 8 OLI

c. Melakukan pemotongan citra dengan batas administrasi desa Lobu Tua.shp

d. Menampilkan Peta Natural desa Lobu Tua

e. Membuat peta kemiringan lereng menggunakan software ArcGIS 10.0 Melakukan Pasca Processing

Mengoverlay peta menggunakan Spatial Analyst Tools di ArcGIS 10, melakukan penjumlahan semua kriteria dengan Raster Calculator, mendapatkan total skor kemudian melakukan penyesuaian sesuai dengan kriteria sehingga didapatkan peta penyebaran situs purbakala di daerah Lobu Tua Kecamatan Andam Dewi Kabupaten Tapanuli Tengah.

Teknik analisa data 
Analisis data yang akan dilakukan, yakni

1. Melakukan koreksi radiometrik menggunakan software ENVI 4.7

2. Membuat peta natural menggunakan software ENVI 4.7

3. Melakukan analisis kemiringan lereng menggunakan ArcGIS 10.0.

\section{HASIL DAN PEMBAHASAN}

1. Hasil Penelitian Geolistrik

Dalam penelitian ini, pengukuran data geolistrik resistivitas konfigurasi schlumberger dilakukan sebanyak 4 lintasan pengukuran dengan panjang lintasan 155 meter dan jarak antar elektroda 5 meter sebanyak 32 elektroda.

Interpretasi Data Geolistrik

Dari hasil nilai resistivitas semu tersebut diolah menggunakan Software Res2Dinv untuk mendapatkan gambaran penampang dua dimensi bawah permukaan sepanjang lintasan, dimana nilai resistivitas yang dibedakan dengan warna untuk melihat kontras resistivitas pada setiap lapisan dan memberikan informasi resistivitas sebenarnya secara vertikal dan horizontal, sehingga dari hasil pencitraan tersebut akan tergambar sebaran situs purbakala yang terdapat di bawah permukaan tanah. Hasil pengolahan data menggunakan Software Res2Dinv untuk setiap lintasan dapat ditunjukkan oleh Gambar 1 sampai Gambar 4.

Lintasan 1

Data diperoleh dengan menggunakan alat geolistrik (Resistivity meter). Pengolahan data menggunakan Software Res2Dinv, diketahui nilai resistivitasnya yaitu $44,8 \Omega \mathrm{m}$ sampai dengan $1820 \Omega \mathrm{m}$. Panjang lintasan yaitu 155 meter dengan jarak antar elektroda yaitu 5 meter. Setelah diinversikan dengan software Res2Dinv diperoleh gambar lintasan 1 sebagai berikut:

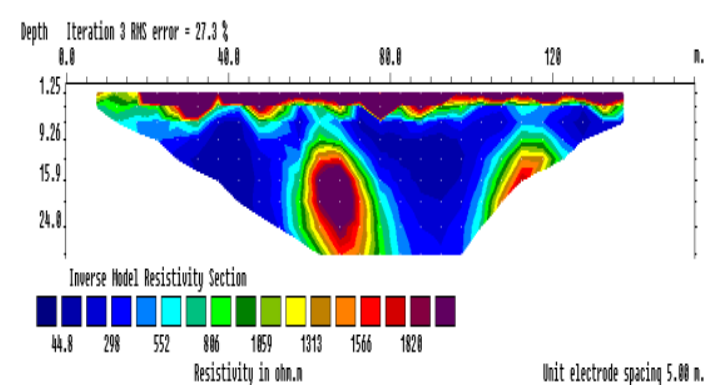

Gambar 1. peta pseudosection lintasan 1

Lintasan 1 melintasi 2 lubang galian, lubang galian pertama memiliki jarak 13 meter dari elektroda 1 dan lubang galian kedua memilliki jarak 12 meter dari lubang galian yang pertama. Pada lintasan 1 yang melintasi lubang galian pertama dapat dianalisis bahwa galian tersebut merupakan kerikil dengan nilai resistivitas $1059 \Omega \mathrm{m}$ dan galian kedua memiliki nilai resistivitas $\quad 1820 \quad \Omega \mathrm{m} \quad$ yang diinterpretasikan sebagai batuan andesit. Lintasan 1 didominasi oleh alluvium yang terdiri dari pasir yang ditunjukkan dengan warna biru pada jarak 70 sampai 110 meter, pada kedalaman 5 sampai 24 meter yang memiliki nilai resistivitas $44,8 \Omega \mathrm{m}$ sampai 552 $\Omega \mathrm{m}$ dan kerikil yang ditunjukkan dengan warna hijau memiliki nilai resistivitas $806 \Omega \mathrm{m}$ sampai $1059 \Omega$ m pada jarak 8 sampai 18 meter dan pada kedalaman 1,25 sampai 5 meter. Sedangkan pada beberapa titik diduga batuan andesit yang terletak pada jarak 55 sampai 80 meter dengan kedalaman 10 sampai 25 meter serta pada jarak 18 meter sampai 128 meter pada kedalaman 1,25 meter sampai 5 meter dan pada jarak 105 meter sampai 120 meter pada kedalaman 10 meter sampai 20 meter yang ditunjukkan dengan warna kuning hingga ungu dengan nilai resistivitas $1313 \Omega \mathrm{m}$ sampai $1820 \Omega \mathrm{m}$. Batuan andesit merupakan salah satu batuan penyusun situs purbakala. Beberapa bagian menunjukkan citra warna yang mencolok perbedaannya yaitu diperkirakan pada lapisan tersebut terdapat material penyusun situs purbakala yang terpendam berupa batuan andesit yang dikelilingi oleh pasir dan kerikil. Selain itu (Sri J.D dkk, 2012) menyebutkan dalam hasil penelitiannya bahwa nilai resistivitas yang 
digunakan untuk menentukan batuan penyusun candi adalah nilai resistivitas batuan andesit dengan range $935 \Omega \mathrm{m}$ sampai $1511 \Omega \mathrm{m}$.

lintasan 2

$$
\text { Pengolahan data menggunakan }
$$

Software Res2Dinv, diketahui nilai resistivitasnya yaitu $44,8 \Omega \mathrm{m}$ sampai dengan $1820 \Omega \mathrm{m}$. Panjang lintasan yaitu 155 meter dengan jarak antar elektroda yaitu 5 meter. Setelah diinversikan dengan software Res2Dinv diperoleh gambar lintasan 2 seperti pada gambar 2

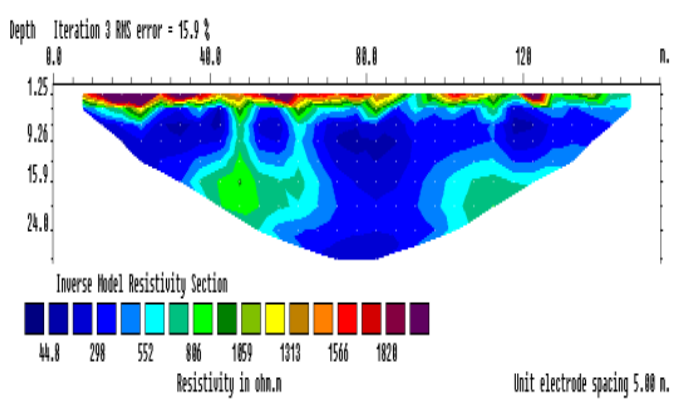

Gambar 2. Peta Pseudosection Lintasan 2

Lintasan 2 melintasi 1 lubang galian, lubang galian tersebut memiliki jarak 28 meter dari elektroda 1. Pada lintasan 2 yang melintasi lubang galian dapat dianalisis bahwa galian tersebut merupakan batuan andesit dengan nilai resistivitas $1566 \Omega \mathrm{m}$. Lintasan 2 didominasi oleh alluvium yang terdiri dari kerikil yang ditunjukkan dengan warna hijau dengan nilai resistivitas $806 \Omega$ m sampai $1059 \Omega$ m pada jarak 35 sampai 70 meter dan pada kedalaman 5 sampai 20 meter. Selanjutnya ada pasir yang ditunjukkan dengan warna biru pada jarak 65 sampai 135 meter dan pada kedalaman 5 sampai 25 meter yang memiliki nilai resistivitas 44,8 $\Omega \mathrm{m}$ sampai $552 \Omega \mathrm{m}$. Sedangkan pada jarak 8 sampai 85 meter terdapat jenis batuan andesit yang diduga sebagai batuan penyusun situs purbakala yang ditunjukkan dengan warna ungu dengan nilai resistivitas $1820 \Omega \mathrm{m}$ pada kedalaman 1,25 sampai dengan 5 meter. Diperkirakan pada lapisan tersebut terdapat batuan penyusun situs purbakala yang terpendam, merujuk pada penelitian terdahulu (Musbikhin, 2013) memperoleh batuan andesit dengan nilai resistivitas 263,74 $\Omega \mathrm{m}$ sampai
2506,13 $\Omega \mathrm{m}$. nilai tahanan jenis dari batuan andesit paling besar dibanding dengan nilai geolistrik tahanan jenis penimbun yang umumnya pasir merupakan material penimbun baru.

\section{Lintasan 3}

Pada lintasan 3 diketahui nilai resistivitasnya yaitu $44,8 \Omega \mathrm{m}$ sampai dengan $1820 \Omega \mathrm{m}$. Panjang lintasan yaitu 155 meter dengan jarak antar elektroda yaitu 5 meter. Setelah diinversikan dengan software Res2Dinv diperoleh gambar lintasan 3 seperti pada gambar 3

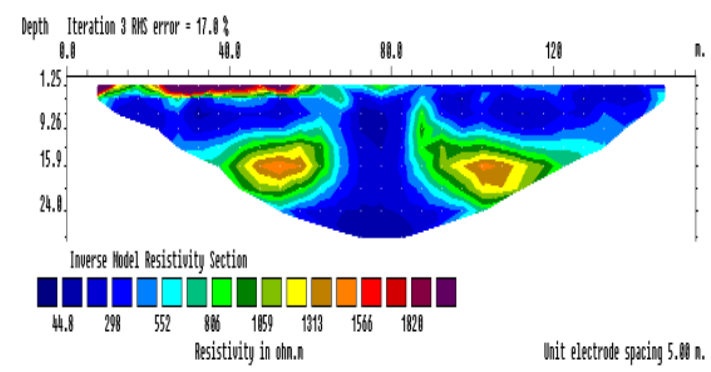

Gambar 3. Peta Pseudosection Lintasan 3

Lintasan 3 didominasi oleh alluvium yang terdiri dari kerikil ditunjukkan dengan warna hijau dengan nilai resistivitas $806 \Omega \mathrm{m}$ hingga $1059 \Omega \mathrm{m}$ pada jarak 85 meter sampai 120 meter dan pada kedalaman 1,25 meter sampai dengan 24 meter. selanjutnya ada pasir yang terletak pada jarak 70 meter sampai dengan 85 meter yang memiliki nilai resistivitas $44,8 \Omega \mathrm{m}$ sampai $552 \Omega \mathrm{m}$. Selanjutnya ada batuan andesit dengan nilai resistivitas yang berkisar antara $1313 \Omega \mathrm{m}$ sampai $1820 \Omega \mathrm{m}$ yang terletak pada beberapa titik yaitu pada jarak 8 meter sampai 58 meter pada kedalaman 1,25 meter sampai 5 meter yang ditunjukkan dengan warna ungu, pada jarak 43 sampai 60 meter dan 95 meter sampai 115 meter dengan kedalaman 10 sampai 20 meter yang ditunjukkan dengan warna kuning hingga merah.

\section{Lintasan 4}

Pada lintasan 4 diketahui nilai resistivitasnya yaitu $44,8 \Omega \mathrm{m}$ sampai dengan $1820 \Omega \mathrm{m}$. Panjang lintasan yaitu 155 meter dengan jarak antar elektroda yaitu 5 meter. Setelah diinversikan dengan software Res2Dinv 
diperoleh gambar lintasan 4 seperti pada gambar 4.

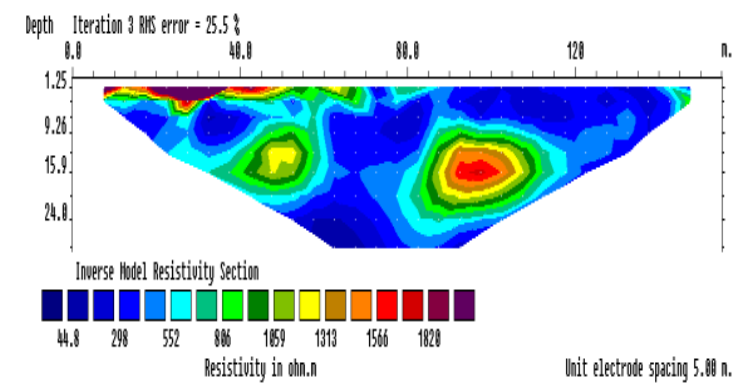

Gambar 4. Peta Pseudosection lintasan 4

Lintasan 4 didominasi oleh alluvium yang terdiri dari kerikil ditunjukkan dengan warna hijau dengan nilai resistivitas $806 \Omega \mathrm{m}$ hingga $1059 \Omega \mathrm{m}$ pada jarak 33 meter sampai 60 meter dan pada kedalaman 10 meter sampai 20 meter. Selanjutnya ada pasir yang ditunjukkan dengan warna biru dengan nilai resistivitas 44,8 $\Omega \mathrm{m}$ sampai $552 \Omega \mathrm{m}$ pada jarak 55 meter sampai 148 meter dan pada kedalaman 1,25 meter sampai 25 meter. Selanjutnya ada batuan andesit dengan nilai resistivitas antara $1313 \Omega \mathrm{m}$ sampai $1820 \Omega \mathrm{m}$ yang diduga sebagai batuan penyususn situs purbakala yang terbagi dalam beberapa titik yaitu pada jarak 8 meter sampai 50 pada kedalaman 1,25 meter sampai 5 meter dan pada jarak 88 meter sampai 108 pada kedalaman 10 meter sampai 20 meter yang ditunjukkan dengan warna kuning hingga ungu. Sesuai penelitian terdahulu (Usmardin dan Sismanto, 2010) dalam penelitiannya memperoleh nilai resistivitas batuan andesit yaitu $750 \Omega \mathrm{m}$ sampai $5000 \Omega \mathrm{m}$.

Untuk sebaran secara vertikal dapat dilihat pada Gambar 5 dengan pengelompokan kedalaman $5 \mathrm{~m}, 10 \mathrm{~m}, 15 \mathrm{~m}, 20$ $\mathrm{m}$ dan $25 \mathrm{~m}$. Sebaran nilai resistivitas pada gambar 5 adalah nilai-nilai yang diambil dari penampang bawah permukaan bumi hasil olahan program software Res2dinv berupa resistivitas model sebenarnya untuk seluruh lintasan. Pada kedalaman $5 \mathrm{~m}$ sampai $25 \mathrm{~m}$ variasi nilai resistivitas yang berkisar antara $44.8 \Omega \mathrm{m}$ sampai $1820 \Omega \mathrm{m}$ dengan interval kontur 126,8 $\Omega \mathrm{m}$. Pada kedalaman tersebut dapat dilihat bahwa daerah anomali terdapat pada beberapa lokasi yang ditunjukkan dengan meningkatnya nilai resistivitas batuan sampai dengan $1820 \Omega \mathrm{m}$.

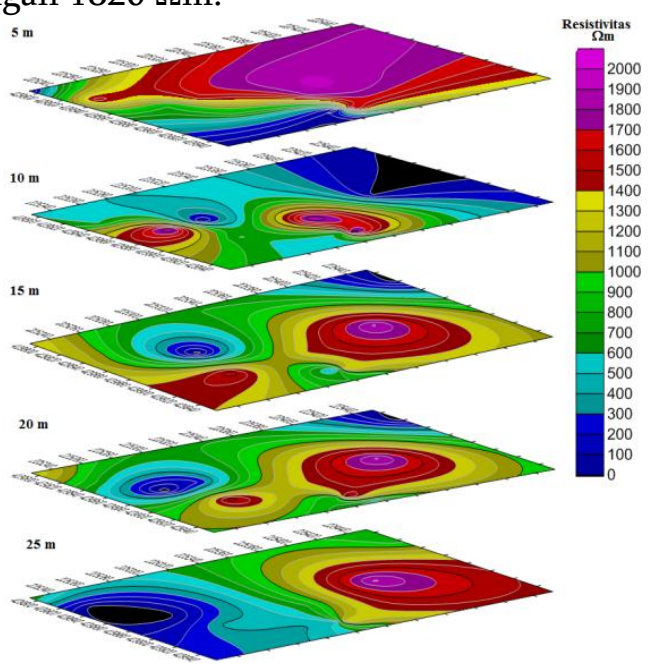

Gambar 5. Kontur variasi kedalaman $5 \mathrm{~m}$ sampai $25 \mathrm{~m}$

Pada beberapa lokasi terlihat adanya kemenerusan anomali dengan bertambahnya kedalaman. Lokasi keberadaan anomali tersebut dapat dibagi dalam 4 lintasan. Dari peta kontur dengan kedalaman $5 \mathrm{~m}$ pada gambar 5 , terlihat sangat jelas adanya anomali resistivitas yang cukup tinggi. Anomali pada setiap lintasan mempunyai nilai resistivitas yang berkisar antara $44,8 \Omega \mathrm{m}$ sampai $1820 \Omega \mathrm{m}$. anomali terlihat semakin berkurang pada kedalaman 10 $\mathrm{m}$, dan pada kedalamaan $15 \mathrm{~m}$ anomali sudah mulai terlihat sampai kedalaman $25 \mathrm{~m}$.

Untuk penampang secara horizontal dapat dilihat pada gambar 6 dengan pengelompokkan jarak $20 \mathrm{~m}, 40 \mathrm{~m}, 60 \mathrm{~m}, 80 \mathrm{~m}$, $100 \mathrm{~m}, 120 \mathrm{~m}$ dan $140 \mathrm{~m}$.

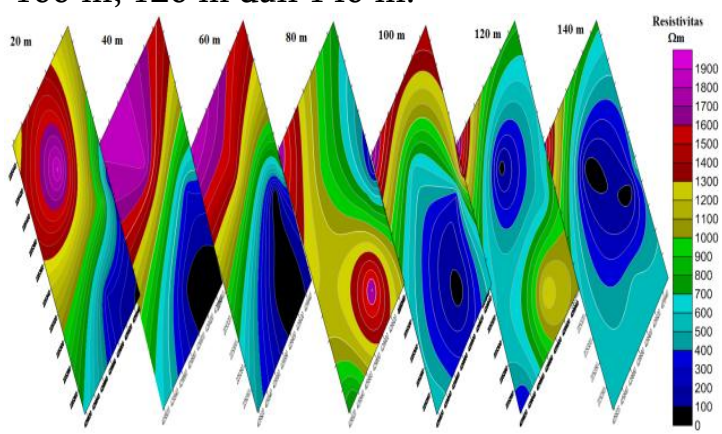

Gambar 6. Resistivitas Penampang Horizontal

Pada penampang horizontal bawah permukaan situs purbakala dibagi kedalam 7 sayatan dengan nilai resistivitas yang berkisar 
antara $44.8 \Omega \mathrm{m}$ sampai $1820 \Omega \mathrm{m}$, dimana setiap sayatan mempunyai citra warna yang berbeda menunjukkan jenis batuan yang berbeda. Pada jarak $20 \mathrm{~m}$ terlihat sangat jelas adanya anomali yang ditunjukkan dengan citra warna merah hingga ungu. Kemenerusan anomali mulai berkurang dari jarak $40 \mathrm{~m}$ sampai jarak $140 \mathrm{~m}$. pada jarak $40 \mathrm{~m}$ sampai $80 \mathrm{~m}$ anomali masih terlihat, dan pada jarak $100 \mathrm{~m}$ sampai $140 \mathrm{~m}$ anomali sudah hampir tidak terlihat.

Berdasarkan informasi nilai resistivitas batuan, informasi geologi, dan survei lapangan, anomali pada lokasi tersebut diperkirakan sebagai batu beku andesit yang menjadi batuan penyusun candi yang masih terpendam.

2. Hasil Penelitian Penginderaan Jauh

Citra Landsat 8 OLI yang digunakan LC81290582016183LGN00 (2016) sumber USGS, untuk menampilkan gambar permukaan menggunakan Landsat 8 OLI, true colour dari hasil RGB 4,3,2 dimana $\mathrm{R}=$ Band 4 (Red), $\mathrm{G}=$ Band 3 (Green) dan B = Band 2 (Blue). Gambar true colour citra pada Landsat 8 OLI dapat dilihat pada Gambar 7.

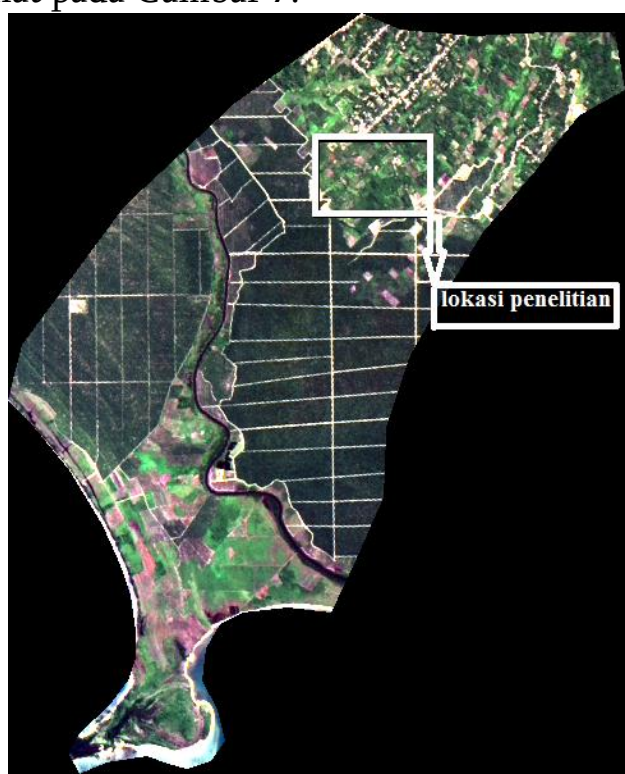

Gambar 7. Citra Landsat 8 OLI

1. Rona

Dari gambar di atas terdapat beberapa rona batuan pada citra. Menurut Ray (1960:6-7 dalam Soetoto, 2015) warna cerah hijau muda merupakan daerah perkebunan, warna hijau tua merupakan daerah persawahan, Warna putih merupakan jalan dan permukiman, Warna putih kebiruan merupakan daerah pinggiran pantai. Way (1973: 5-6 dalam Soetoto, 2015) menyebutkan bahwa ragam rona dari gambar 4.8 menunjukkan rona uniform yang berarti daerah Alluvium.

\section{Relief}

Adalah beda tinggi antara puncak timbulan dan dasar lekukan, juga curam landainya lereng-lereng yang ada di daerah tersebut. Dapat dilihat pada gambar 8 dibawah ini.

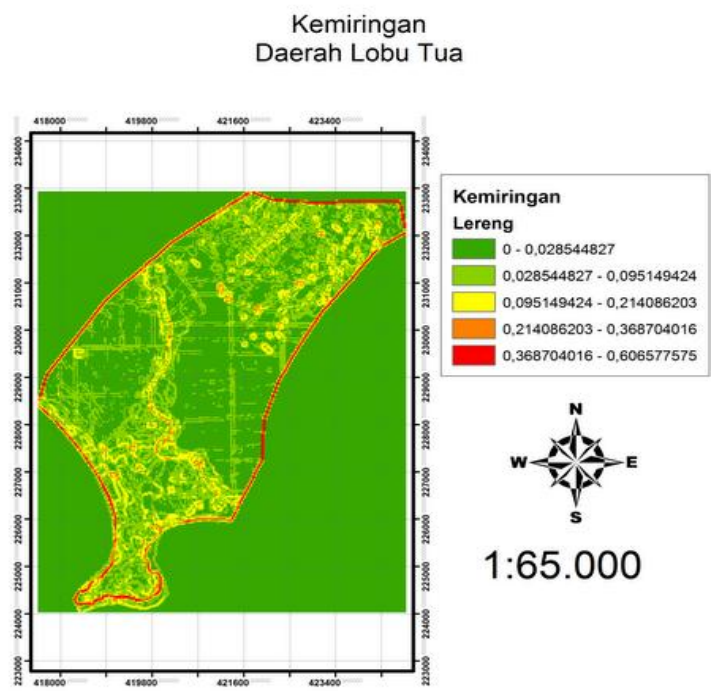

Gambar 8. Kemiringan Lereng

Gambar di atas memiliki nilai kemiringan lereng $0-0.6 \%$ berdasarkan tabel Soetoto dan tabel Zuidam maka dapat diinterpretasikan bahwa daerah penelitian mempunyai topografi datar atau hampir datar sehingga dapat ditentukan jenis batuannya yaitu endapan Alluvial (Alluvium).

Sesuai dengan peta geologi, daerah penelitian berbatasan langsung dengan laut dan didominasi oleh batuan alluvium, yang terdiri dari kerikil dan pasir.

\section{KESIMPULAN}

Dari hasil penelitian yang telah dilakukan maka dapat disimpulkan:

1. Penyebaran resistivitas bawah permukaan di desa Lobu Tua dengan menggunakan metode geolistrik 
konfigurasi schlumberger Kabupaten Tapanuli Tengah terdapat batuan andesit pada seluruh lintasan dengan nilai resistivitas $44,8 \Omega \mathrm{m}-1820 \Omega \mathrm{m}$.

2. Penyebaran resistivitas bawah permukaan di Desa Lobu Tua Kabupaten Tapanuli Tengah pada penampang vertikal didapatkan adanya batuan andesit pada kedalaman 5 meter sampai 25 meter dengan nilai resistivitas $1313 \Omega \mathrm{m}-1820 \Omega \mathrm{m}$ dan pada penampang horizontal batuan andesit didapatkan pada jarak 20 meter sampai 140 meter dengan resistivitas $1313 \Omega \mathrm{m}-1820 \Omega \mathrm{m}$.

3. Hasil pemetaan di Desa Lobu Tua menggunakan citra satelit landsat 8 OLI menunjukkan bahwa daerah tersebut didominasi oleh batuan endapan Aluvial (Alluvium).

DAFTAR PUSTAKA

Ambary, H.M., (2001), Menemukan Peradaban Jejak Arkeologis dan Historis Islam Indonesia Cet. II, Logos Wacana Ilmu, Jakarta.

Anthony, R., (1969), The Contest, for North Sumatera, Acheh, The Netherlands and Britain, 1858-1898, Press-Oxford, New York.

Guillot, C., (2014), Lobu Tua Sejarah Awal Barus, Yayasan Pustaka Obor, Jakarta.

Galili, E., Evron, M.W., Ronen, A., Quaternary, R., (1988), Elsevier Holocene sea level changes based on submerged archaeological sites off the northern Carmel coast in Argentina, Volume 29. Issue 1, hal.1-91.

Hendrajaya, L., Idham, A., (1990), Geolistrik Tahanan Jenis, Laboratorium Fisika Bumi Jurusan Fisika FMIPA ITB, Bandung.

Hendro, S., (2005), Pariwisata Dan Pelestarian Situs (Studi Tentang Upaya Pelestarian Situs Trowulan Melalui Pariwisata), Pusat Penelitian dan Pengembangan
Pariwisata departemen Kebudayaan dan Pariwisata, Jakarta.

Musbikin., (2013), Aplikasi Metode Geolistrik Resistivitas Schlumberger Dalam Memperkirakan Keberadaan Batuan Penyusun Candi Kadisoka, Skripsi, Universitas Islam Negeri Sunan Kalijaga, Yogyakarta.

Purbowaseso, B., Sutanto., (1995), Penginderaan Jauh Terapan, Universitas Indonesia Press, Jakarta.

Ray, R.G., (1960). Aerial Photographs in Geologic Interpretation and mapping, United States Government Printing Office, Washington.

Rokhmana, C.A., Potensi Pemanfaatan Penginderaan Jauh Dengan Wahana Udara Nir-Awak Di Industri Tambang Dan Migas, Semnas IF 2012, 1979-2328.

Soetoto, S.U., (2015), Penginderaan Jauh Untuk Geologi, Ombak, Yogyakarta.

Sri, J.D., Darsono., Legowo, B., (2012), Identifikasi Situs Candi Bukit Carang, Karanganyar Menggunakan Metode Geolistrik Tahanan Jenis Konfigurasi Dipol-Dipol, Indonesian Journal of Applied Physics, Vol.2, No.1, hal.45.

Usmardin., Sismanto., (2010), Penyebaran Batuan Situs Purbakala Candi Palgading di Dusun Palgading, Desa Sinduharjo, Kecamatan Ngaglik, Kabupaten Sleman, Daerah Istimewa Yogyakarta dengan Menggunakan Metode Resistivitas Dipole Dipole, Jurnal Sains Dan Teknologi Lingkungan,

Volume 2, Nomor 2, Hal 111-119.

Way, D.S., (1973), Terrain Analysis, A. guide to Site Selection Using Aerial Photographic Interpretation, Dowden, Harvard University Community Development Series. 